\title{
The Agreement of Bank Cooperation with Agent in Providing Branchless Banking with The Realization of Inclusive Finance
}

\author{
Etty Mulyati
}

Universitas Padjadjaran, Indonesia

E-mail:etty.mulyati@unpad.ac.id

Submitted: February 10, 2021; Reviewed: March 18, 2021; Accepted: March 26, 2021

Article Info

Abstract

Keywords:

Agreement, Bank, Clever Agent, Inclusive Finance.

DOI:

10.25041/fiatjustisia.v15no4.2269
Expanding access to financial services is essential for all levels of society, considering that many community members still do not know, use, and get banking services and other financial services. Through Branchless Banking, banking products can be reached according to the community's needs to support financial inclusion. In implementing innovative banking practices, the banking industry collaborates with other parties, namely agents supported by information technology facilities. This innovation is carried out electronically and involves third parties outside the bank. In this case, the agent is very vulnerable to risk. The problem is the principle of prudence in the cooperation agreement and the bank's responsibility if the agent in implementing Branchless Banking services harms its customers. The approach method used is the normative juridical approach, which includes research on a positive legal inventory and legal principles and rules governing legal relations. The principle in the prudence of banks regarding cooperation agreements with agents provide Branchless Banking services to support the realization of financial inclusion. Banks are required to implement risk management effectively using information technology, Know Your Customer Principles and Anti Money Laundering, Customer Due Diligence, and in-depth analysis of the assessment of credit applications by debtor customers. The bank is responsible for compensating for the losses if the agent implementing the intelligent behaviour of services harms his customers, considering the agent is acting for and on behalf of the bank. Even though the bank 
has not made a mistake, the agent is an extension of the bank, 1367 of the Civil Code that a person will also be responsible for people's actions under his/her dependents or objects under his/her supervision.

\section{A. Introduction}

Banking institutions play an essential strategic role in encouraging the economic development of a country; banking institutions must act as agents of action to find national goals and not become a burden and obstacle in implementing national development. ${ }^{1}$ Banking institutions play a role in maintaining the balance of progress and national economic unity due to stability in the banking industry will significantly affect the economy's resilience. ${ }^{2}$

The development of the national and international economies, which are rapidly accompanied by growing challenges, must immediately be followed by creating the national banking system. Carry out its functions and responsibilities to the community. The role of banking dramatically affects the economic activities of a country. Banks can be said to be the blood of a country's economy. The progress of a country's bank can also be used to measure the country's progress. ${ }^{3}$ The more developed a country is, the more significant the role of banks in controlling their country, meaning that the government and its people increasingly need the existence of the banking world. ${ }^{4}$

In the context of realizing a prosperous Indonesia, strengthening macroeconomic stability must be carried out by enhancing banking restructuring efforts and controlling banking financial institutions to strengthen the role of these institutions as intermediaries to production sectors. ${ }^{5}$ Banks are part of the financial and payment of a country. Even in this era of globalization, banks have also become part of the world's financial and payment. A bank that has obtained a standing and operating license from the monetary authority, then the bank belongs to the public. Therefore, its

\footnotetext{
${ }^{1}$ Hermansyah, Hukum Perbankan Nasional Indonesia (Jakarta: Prenada Media Group, 2007).

${ }^{2}$ Putu Ayu Sruti Permata Sari and Budi Frensidy, "Analisis Penerapan Program Laku Pandai Pada PT XYZ," Jurnal Ilmu Manajemen Dan Bisnis 10, no. 2 (2019): 131-42, https://doi.org/10.17509/jimb.v10i2.16997.

3 Prani Sastiono and Chaikal Nuryakin, "Inklusi Keuangan Melalui Program Layanan Keuangan Digital Dan Laku Pandai," Jurnal Ekonomi Dan Pembangunan Indonesia 19, no. 2 (2019): 242-62, https://doi.org/10.21002/jepi.v19i2.1228.

${ }^{4}$ Kasmir, Dasar-Dasar Perbankan (Jakarta: Raja Grafindo Persada, 2002).

5 dian Cahyaningrum, "Pelindungan Nasabah Dalam Penyelenggaraan Laku Pandai: Studi Pelindungan Nasabah Laku Pandai Bca Di Jawa Tengah Dan Bri Di Papua (Consumer Protections In 'Laku Pandai' Implementation: Study Of Bca 'Laku Pandai' Consumer Protection In Middle Java And Bri 'Laku Pandai' Consumer Protection In Papua)," Negara Hukum: Membangun Hukum Untuk Keadilan Dan Kesejahteraan 7, no. 2 (2017): 213-34, https://doi.org/10.22212/JNH.V7I2.932. 
existence must be maintained by the bank owners themselves and the national and global community. ${ }^{6}$

It is hoped that banks that control and dominate the financial industry in Indonesia are highly expected to build public financial services that more people can enjoy. Efforts to expand public financial access are priorities for the Financial Services Authority, Bank Indonesia, and central and local governments. This is because access to finance is closely related to improving people's welfare and supporting the availability of sources of finance for national economic developments.

There is a need to expand financial services to the public because Indonesia has a low level of financial inclusion when compared to neighbouring countries. The National Council for Financial Inclusion noted that financial inclusion had reached $75 \%$ in 2019, but financial literacy is only around $35 \%$. $^{7}$

The knowledge and understanding of the Indonesian people towards financial institutions, products, and services will be relatively low and uneven in every financial services industry sector. This affects the common utilization of financial institutions, products, and services. On the other hand, the per capita Gross Domestic Product of the Indonesian people is experiencing growth. This growth is expected to be followed by the community's ability to utilize financial products and/or services following their needs and capabilities. Therefore, to increase the public needs to have knowledge and understanding of financial institutions, products, and services, activities to increase financial literacy. Efforts to improve Financial Literacy are carried out by the Financial Services Authority, including by issuing the National Strategy for Indonesian Financial Literacy on 19 November 2013. This strategy subsequently becomes a reference for various parties, not only in the implementation of Financial Education but also in developing schemes for products and/or financial services.

This strategy is designed to respond to a national survey covering Financial Literacy and Financial Inclusion in the Indonesian public. This survey was conducted on 8,000 respondents spread across various regions of Indonesia. Efforts to improve Financial Literacy are carried out through the implementation of Financial Education. The education begins with a basic introduction to Financial Services Institutions and the characteristics, benefits, costs, and risks of a financial product and service and personal financial management, which are expected to bring positive changes to financial behaviour. Such Financial Education needs to be supported by adequate infrastructure and implemented with due observance to the principles of being planned and measured, oriented towards achievement, sustainability, and

\footnotetext{
${ }^{6}$ Sutan Remy Sjahdeini, "Rahasia Bank:Berbagai Masalah Disekitarnya" (Jakarta, 2008), https://korup5170.files.wordpress.com/2008/06/rahasiabank.pdf.

7 Tesa Oktiana Surbakti, "OJK Terus Tingkatkan Akses Keuangan Masyarakat," accessed February 10, 2021, https://mediaindonesia.com/ekonomi/276954/ojk-terus-tingkatkan-akseskeuangan-masyarakat.
} 
collaboration. Furthermore, increasing public Financial Literacy will direct the public to better understand social and economic policies and understand their rights and obligations as consumers. ${ }^{8}$ With a good understanding and awareness of the importance of financial institutions, products, and services, people can choose and utilize Financial institutions. Products and services must be based on their needs and abilities to increase the level of welfare.

Increasing financial literacy also needs to be balanced with growth in financial inclusion achieved through the following ways: (1) The public can take advantage of financial institutions, products, and/or services; (2) According to consumer and/or public demand and the ability to provide financial products and/or services. The availability of these financial products and/or services can be obtained by planning or developing financial products and/or services so that, in the end, they can be utilized by all groups (especially the lower middle class).

As a vital part of financial inclusion activities, banking has a strategic role in expanding financial services to the public. Banks have committed to developing financial inclusion by expanding financial services to the public through banking to establish financial inclusion in Indonesia. Financial inclusion is a comprehensive activity that aims to remove all forms of barriers to public access in utilizing financial services supported by various supporting infrastructures.

Access to financial services is necessary for people who don't know how to use and/get service and other services. To expand access to financial services, the Financial Services Authority, The banking industry, and other financial industries are also committed to supporting the government and also proclaiming the realization of financial inclusion..$^{9}$ One manifestation of the commitment of the financial services industry that has been set forth as one of the National Strategy for Financial Inclusion programs is the provision of branchless banking services through branchless banking. The existing financial products are easy to obtain, easy to understand and meet the needs of society to support financial inclusion. ${ }^{10}$

Based on this background, the US Financial Services Administration Regulation No. 19/POJK.03/2014 concerning Non-Office Financial Services

\footnotetext{
${ }^{8}$ Syah Amelia Manggala Putri and Eka Jati Rahayu Firmansyah, "Optimalisasi Laku Pandai Berbasis Masjid Guna Literasi Dan Inklusi Keuangan Syariah Berkelanjutan," Jurnal Ekonomi Dan Bisnis Islam (Journal of Islamic Economics and Business) 3, no. 2 (2017): 106, https://doi.org/10.20473/jebis.v3i2.6464.

${ }_{9}^{9}$ Puji Muniarty, Nurhayati Nurhayati, and Ita Purnama, "Analisis Laku Pandai (Branchless Banking) Pada Agen Perbankan (Studi Di Kota Bima)," Jurnal Mitra Manajemen 3, no. 7 (2019): 802-14, https://doi.org/10.52160/ejmm.v3i7.259.

${ }^{10}$ I. E. D.T.Stamatopoulos Thalassinos and E. P. Thalassinos, "The European Sovereign Debt Crisis and the Role of Credit Swaps. Chapter Book W. T. Ziemba and A.G. Malliaris,' The WSPC Handbook of Futures Markets' (Eds), In Memory of Late Milton Miller (Nobel 1990) World Scientific Handbook in Financial Economics," 5, 2015, https://doi.org/10.1142/9789814566926_0020. 
for Financial Inclusion. In his explanation, banking and other financial services are crucial to support Indonesia's economic growth and activity. In recent developments, every industry needs to improve and expand access to financial services to provide better services to all levels of Indonesian society, especially those who do not understand, take advantage of, and/or have many benefits. There are many reasons for Indonesia's limited access to banking and financial services, including ${ }^{11}$ : a. many parts of Indonesia do not yet have a network of financial services offices due to remote locations; $b$. the costs that need to be incurred are quite high and/, or it takes a long time for people in remote areas to reach financial service locations; c. the complexity of the process of banking services and other financial services; d. Inadequate knowledge and understanding of financial products and services; and/or e. The income of some people is still low, so they are unable to save money. Expanding access to financial services is certainly very necessary for all levels of society, both those who live in remote areas and those with low income.

With increasingly inclusive financial services, it is hoped that it will have an impact on increasing the number of parties involved in addition to the government and the private sector and the community. Moreover, these services can encourage economic growth so that welfare is more evenly distributed throughout Indonesia and can play a role in poverty alleviation efforts. The role of the financial services industry, especially banking, in boosting the economy, among others, is through the intermediation function by channelling productive credit and/or other credit to the public as a whole. ${ }^{12}$

Considering that many people do not know, do not use, and cannot obtain banking services and other financial services, it is necessary to "smart practice" because they live far from bank offices or burdensome fees or conditions. The existing branchless banking business needs to be developed so banking and other financial services can reach all levels of society throughout Indonesia. Branchless Banking aims to support economic growth and equitable development between regions, mainly villages and eastern Indonesia, by providing access for the small community to conduct financial transactions, especially banking, wherever the community is located. ${ }^{13}$

Branchless banking is a process of cooperation with other parties (agents) to provide banking services and/or other financial services supported by information technology facilities. Branchless Banking utilizes cellular telephones, Electronic Data Capture, and/or internet banking that supports financial services by banks through agents. The products provided by the Financial Services Institutions that carry out Smart Practice include a.

\footnotetext{
${ }^{11}$ Thalassinos and Thalassinos.

12 Regulation of the Financial Services Authority No. 19 / POJK.03 / 2014 concerning Officeless Financial Services in the Context of Financial Inclusion

${ }^{13}$ Lukmanul Hakim et al., "Legal Aspects of Micro Business Development Institutions in State Purpose of Welfare," Fiat Justisia: Jurnal Ilmu Hukum 14, no. 3 (May 15, 2020): 260, https://doi.org/10.25041/fiatjustisia.v14no3.1804.
} 
Savings; b. Credit micro customers; c. Microinsurance; and d. Based on other financial products approved by the Financial Services Authority.

The simple concept of Branchless Banking is that the selection and training of agents are carried out by the Branchless Banking implementing bank to become service provider agents. Also, agents are provided with ways to provide insights for saving and making transactions. Thus, the persistence of agents is expected to grow the confidence of our brothers and sisters in remote areas to take advantage of financial services (inclusive finance). The Financial Services Authority, together with 17 banks and 350,000 agents, is believed to cover $75 \%$ of the archipelago. Banks that have launched the Branchless Banking program include PT Bank Rakyat Indonesia (BRI) in Papua and PT Bank Mandiri Tbk in Makassar. There are also PT Bank Tabungan Pensiunan Nasional Tbk (BTPN) serving customers in Lubuk Pakam North Sumatra, PT Bank Central Asia Tbk (BCA) in Grobogan, PT Bank Negara Indonesia Tbk in Bima, and PT Bank Tabungan Negara Tbk in Palangkaraya. ${ }^{14}$

Agents are third parties who work with banks and act on behalf of the bank to provide intelligent behavioural services. Agents scattered in various locations can replace branches to reach people who have not been exposed to banking services. The existence of an Agent can reduce shipping costs and increase convenience for customers. From the bank side, the provision of banking services with Branchless Banking can save quite a lot of costs, reducing the cost of opening a branch office which can cost at least Rp. 1.000.000.000 and is still cheaper than building an ATM (Automatic Teller Machines) whose investment requires at least Rp. 60.000 .000 per ATM. ${ }^{15}$

Banks will have agents who will be partners from individuals or legal entities such as cooperatives, retailers, post offices, or other institutions recognized and agreed upon in a cooperation agreement between the bank and the agent. Anyone who becomes an agent as an extension for the bank in providing banking services must provide good services to customers, organize all administrative activities and manage the amount of cash available, and manage the availability of customer funds at the agent. ${ }^{16}$ This innovation is carried out electronically and involves third parties outside the bank. In this case, the agent is very vulnerable to risk, which means that if the bank is not careful in choosing its partners, it will cause problems. Based on this, the bank's principles due to prudence towards Cooperation agreements with

\footnotetext{
14 "Laku Pandai - Layanan Keuangan Untuk Semua," accessed February 10, 2021, https://sikapiuangmu.ojk.go.id/FrontEnd/CMS/Article/191.

${ }^{15}$ Roby Rushandie, "Branchless Banking Lebih Dari Sekedar Jargon Marketing," accessed 10 February 2021, http://www.kompasiana.com/rushandie/branchless-banking-lebih-darisekedar-jargonmarketing_54f94820a3331150278b4816.

16 Priadhi Harry Ramdhany, "Hubungan Hukum Antara Bank Dengan Agen Laku Pandai (Branchless Banking) Dalam Pelaksanaan Perantara Keuangan (Financial Intermediary) Dihubungkan Dengan Prinsip Kepercayaan (Fiduciary Principle)," Aktualita (Jurnal Hukum) 2, no. 2 (2019): 455-72, https://doi.org/10.29313/aktualita.v2i2.4841. 
agents that provide Branchless Banking services to support the realization of financial inclusion and the bank's liability if the agent commits a violation that causes losses to customers in implementing smart behaviour services. ${ }^{17}$

The method used is the normative juridical method, which includes studying the list of positive laws and the study of legal principles and rules of legal relations. This research will examine the principle of bank prudence regarding cooperation agreements with agents in providing services to support the realization of financial inclusion and the bank's liability if the agent commits a violation that causes losses to customers in implementing smart behaviour services. The specification of this research is analytical descriptiveanalytical in nature after doing descriptions of various legal aspects. This research will describe various legal problems through a positive law inventory, the discovery of legal principles. Then the qualitative juridical data analysis was carried out, the data were arranged systematically for further qualitative analysis, the results obtained were manifested in the form of description. ${ }^{18}$

\section{B. Discussion}

\section{Cooperation Agreement between Bank and Agent in Providing Smart Practice Services}

A deal is an event where a person promises one or two people to promise each other something to do. As a result of this incident, there is a legal relationship between two or more people, called an agreement, as in Article 1313 of the Civil Code: "An agreement is an act in which one or more people bind themselves to one or more other people".

The legal relationship referred to in Describe the relationship between legal requirements and consent and has legal consequences. A relationship that is outside the legal environment is not an agreement. In a legal relationship, if one party does not fulfil his promise voluntarily, the party who feels aggrieved can sue in court to accomplish achievement. ${ }^{19}$

The legal relationship that often occurs is based on an agreement. Therefore it can be said that the agreement has a significant role in the engagement. In the form of an agreement, a series of words containing a

\footnotetext{
17 Rizki Mubarok, Budi Santoso, and Rinitami Njatrijani, "Pertanggungjawaban Agen Branchless Banking Terhadap Nasabah Branchless Banking (Hubungan Hukum Antara AgenPrinsipal Dan Konsumen)," Diponegoro Law Journal 6, no. 2 (2017): 1-12, https://ejournal3.undip.ac.id/index.php/dlr/article/view/19636.

18 Mukti Fajar. and Yulianto Achmad., Dualisme Penelitian Hukum Normatif Dan Empiris (Yogyakarta: Pustaka Pelajar, 2010).

19 Ajeng Noorseta Quadtias Kumitirasih, "Tanggungjawab Agen Layanan Keuangan Tanpa Kantor Dalam Rangka Keuangan Inklusif Terhadap Rahasia Bank," Kumpulan Jurnal Mahasiswa Fakultas Hukum,

(2015), http://hukum.studentjournal.ub.ac.id/index.php/hukum/article/view/1160.
} 
pronounced or written promise or ability. Meanwhile, what is called an agreement refers to a legal relationship between two or two parties. On this basis, one party has the right to request something from the other party, and the other party is obliged to fulfil the request. The party entitled to demand something is called a creditor or debtor, and the party obliged to carry out a bill is called a debtor. ${ }^{20}$

The agreement's validity must meet the four requirements specified in Article 1320 of the Civil Code. The first and second clauses relate to the subject or party to the agreement so that they are called subjective conditions, while the third and fourth terms are called objective conditions because it concerns the purpose of the agreement. If the conditions are not met in an objective condition, the agreement is invalid, which means that the agreement was never established or included from the start. As for the subjective conditions, if the conditions are not met, the agreement can be cancelled at any time. Therefore, as long as either party has no request to cancel it, the agreement reached remains valid and binding on both parties. ${ }^{21}$

The first condition, agreeing that those who bind themselves, implies that the negotiating parties have agreed or adjusted their will or mutually combined each other's will, born without coercion, error, or fraud. Which agreement can be expressed explicitly or tacitly. ${ }^{22}$ An agreement can be understood as a logical encounter. "Agreement is a coming together of mind; a coming together in opinion or determination; the coming together in accord of two minds on a given proposition. The union or two more minds in a thing done or to be done, mutual consent to do thing agreement is a broader term, e.g. an agreement might lack an essential element of contract", ${ }^{23}$ In other words, the agreement is the meeting of two or more reasons about something that can be done or will be done widely; the agreement is interpreted as a reciprocal agreement to do something.

The second requirement, namely having the ability to participate, is a general requirement to legally take action: it must be mature, have a sound mind, and not be prohibited by a statutory regulation from committing a particular act. ${ }^{24}$ The third requirement is related to the object to which an agreement was achieved or reached. According to Article 1333 of the Civil Code, commodities as the agreement's object must be determined. Article 1334 of the Civil Code also stipulates that only goods provided in the future can be the object of an agreement. The four conditions are causality, which is the legal meaning of the agreement or the purpose. Article 1335 of the "Civil Code" stipulates no causal agreement, and an agreement made for wrong

\footnotetext{
${ }^{20}$ Subekti, Hukum Perjanjian (Jakarta: Intermasa, 2005).

${ }^{21}$ Subekti.

${ }^{22}$ Riduan Syahrani, Seluk Beluk Dan Asas-Asas Hukum Perdata (Bandung: PT.Alumni, 2004).

${ }^{23}$ Catherine Tay Swee Kian and Tang See Chim, Contract Law (Singapore: Times Books International, 1993).

${ }^{24}$ Riduan Syahrani, Seluk Beluk Dan Asas-Asas Hukum Perdata. 
reasons or prohibitions has no rights. Also, Article 1337 of the Civil Code stipulates that cases in the agreement must not conflict with the law, decency, and public order.

In the Agreement Law, the principle of freedom of contract is very well known, namely the principle that stipulates that as long as it does not violate the law, basically everyone can enter into a contract (or agreement) with anyone and determine the contents of the contract. any deal., Morality and public order. Article 1338 (1) of the Civil Code stipulates that all agreements made legally apply to the person agreeing. Based on this principle, various agreements arise in society, including cooperation agreements.

The cooperation agreement contains a written agreement clause between two or more parties regarding their respective rights and obligations, binding the cooperating parties to achieve the agreement between the bank and the agent. Agents are authorized to act for and on behalf of the bank to carry out business transactions with other parties. An Agent in the Branchless Banking mechanism means acting for and on behalf of the bank, simplifying the complexity of banking administration and eliminating the distance between customers. ${ }^{25}$

Based on Article 16 of the Financial Services Authority Regulation for Smart Practice:

"(1) Branchless Banking organizing banks cooperate with agents to provide bank products for people whom a bank office network has not served.

(2) Agent as intended in paragraph (1) can be:

a. Individual agent; and/or

b. Agents with legal entities ".

Thus the Branchless Banking agent is an extension of the bank's arm to provide financial services, which may include: Individuals, such as teachers, retirees, traditional heads, shop owners, and so on; or legal entities, such as Limited Liability Companies, Regional Companies, or Cooperatives. Branchless Banking agents can be found in all regions of Indonesia with the operational area where the agent resides (individual) or is located for business (legal entity).

Agents are parties that cooperate with banks. Apart from conducting financial service transactions, agents also have other duties: the objectives of Officeless Financial Services in the Framework of Financial Inclusion or what is known as Branchless Banking. This is financial education to the public. The goal is that people become aware of and have a desire to use existing financial service facilities. ${ }^{26}$

The duties of the agent written in the Financial Services Authority Regulation for Smart Practice Article 19 Paragraph 2 are:

\footnotetext{
${ }^{25}$ Primitiva Febriarti, “Agen Sang Ujung Tombak," in Gerai Info Bank Indonesia, June 2013.

26 Rivki Maulana, "OJK Andalkan Agen Laku Pandai," bisnis.com, 2015, https://finansial.bisnis.com/read/20150413/90/422379/ojk-andalkan-agen-laku-pandai.
} 
a) Transactions related to savings with the BSA feature, including opening accounts, cash deposits, withdrawals, bookkeeping, bill payments, fund transfers, balance checks, and/or checkout.

b) Transactions related to credit or financing of small customers, including receiving application documents, making payments, issuing invoices, or receiving instalments and/or principal repayments.

c) Apart from deposits with BSA characteristics, transactions related to deposits include cash deposits and withdrawals, overbooking, payments, and/or transfers of funds.

d) Transactions related to services or other financial services following applicable regulations.

The Branchless Banking agent provides various banking products that are simple, easy to understand, and under the community's needs, such as savings and transfer services. Some agents have even provided financial products such as micro-insurance and People's Business Credit (KUR). There is identification on each Laku Pandai agent that includes the Bank logo, the "Branchless Banking" logo, and each agent's letter of appointment from the bank. The Branchless Banking agent can carry out several financial transactions without going far or queuing at the bank branch.

The agent is branchless banking services, which is believed to be an innovation of optimizing the function of a bank because the agent's role expands the distribution of financial services to middle and lower class groups of society, especially those who have not obtained access to banking services. The agent's function is as an intermediary that carries out banking services and deals directly with service users, both customers and non-bank customers, and executing the function of the bank as an intermediary financial institution that banks cannot optimally implement due to limited access. ${ }^{27}$

\section{Regulation of Financial Services Without Smart Practice}

Branchless banking is an Officeless financial service within the framework of financial inclusion. Program is a cooperation program with other parties (bank agents) to provide banking services and/or other financial services supported by information technology facilities. Considering that many community members do not know, use and obtain banking and other financial services, it is necessary to carry out a panda behaviour, especially because they live far from bank offices and/or burdensome fees or requirements. The Financial Services Authority, banking, and financial services industry are committed to supporting the realization of financial inclusion. To that end, the Government of Indonesia launched a National Inclusive Financial Strategy in June 2012, one of which is branchless banking. The existing branchless

\footnotetext{
${ }^{27}$ Inda Rahadiyan and M. Alif Akbar Pranagara, "Bentuk Hubungan Hukum Para Pihak Dan Tanggung Jawab Agen Dalam Penyelenggaraan Branchless Banking Di Indonesia," Jurnal Hukum Ius Quia Iustum 24, no. 2 (2017): 314. 
banking business needs to be developed to popularise banking services and other financial services by all levels of society in Indonesia.

A bank can become a branchless banking operator based on Article 10 of the Branchless Banking Regulation, a bank applying for approval to become a Branchless Banking operator must meet the following requirements:

a. having an Indonesian legal status;

b. has a risk profile rating, operational risk level, and compliance risk with a rating of 1,2 , or 3 ;

c. Office network in eastern Indonesia and/or East Nusa Tenggara; and

d. already has the supporting infrastructure to provide electronic transaction services for Bank customers in the form of:

1. Short Message Service banking or mobile banking, and

2. Internet banking or host to host.

The Financial Services Authority may conduct periodic evaluations regarding the Bank office network area requirements as referred to in paragraph (1) letter c.

Based on his explanation, services include obtaining information, communicating, and carrying out banking transactions through electronic media. "Short Message Service banking" is defined as banking information or transaction services that can be accessed directly through cellular phones using the Short Message Service. The Message is referred to in the provisions concerning business activities and office networks based on the core capital of commercial banks. The term "mobile banking" is defined as a service for conducting banking transactions via cellular phones, as defined in the provisions Business activities and office networks based on core capital. "Internet banking" is defined as a service for conducting banking transactions via the internet network, as defined in the provisions Business activities and office networks based on core capital. What is meant by "host to host" is an encrypted electronic system connected in two directions and real-time online between two institutions that cooperate. ${ }^{28}$

The purpose of branchless banking services is to provide easy-tounderstand and straightforward financial products that can meet the needs of people who are currently unable to obtain financial assistance. With the increasing number of members of various groups of society using financial services through banking in multiple regions in Indonesia, it is hoped that community economic activities can run smoothly to encourage economic growth and equitable development in the various areas in Indonesia. Especially between regions (throughout Indonesia), State, and city. ${ }^{29}$

\footnotetext{
${ }^{28}$ Edquist $\mathrm{C}$ and Hommen L, "Systems of Innovation: Theory and Policy for the Demand Side," Technology in Society21, 1999, 63-79.

29 Danrivanto Budijanto, Hukum Telekomunikasi, Penyiaran Dan Teknologi Informasi: Regulasi Dan Konvergensi (Bandung: Refika Aditama, 2010).
} 
Branchless Banking services in the form of Savings with the characteristics of a basic saving account (BSA), credit/financing for small customers, and other financial products (such as micro-insurance). It is contained within Article 4: "Products that can be provided by the Financial Services Institutions that carry out Branchless Banking, include:

a. Savings;

b. credit or financing for micro customers;

c. Microinsurance; and/or

d. Other financial products based on the approval of the Financial Services Authority".

The products are described in Article 5:

(1) Savings, as referred to in Article 4 letter a, have Basic Saving Account characteristics.

(2) The characteristics of the Basic Saving Account as referred to in paragraph

(1) are as follows:

a. individual Indonesian citizens can only own;

b. in Rupiah currency;

c. no minimum deposit limit;

d. no minimum account balance limit;

e. the maximum limit on the account balance at any time is set at a maximum of Rp.20,000,000.00 (twenty million rupiahs);

f. Maximum limit for debit transactions in the form of cash withdrawals, book-entry and/or outgoing transfers within 1 (one) month cumulatively for each account is a maximum of IDR 5,000,000.00 (five million rupiahs);

g. The bank may determine the maximum limit for debit account transactions as referred to in letter $\mathrm{f}$ to be greater than Rp.5,000,000.00 (five million rupiahs) in 1 (one) month, but not greater than Rp.60,000,000.00 (sixty million rupiahs) within 1 (one) year cumulatively, if the customer is also a Bank debtor;

h. exempted from charging fees for:

1. monthly administration,

2. open an account,

3. cash deposit transactions,

4. incoming transfer transactions,

5. book-entry transactions, and

6. closing accounts;

i. fees for cash withdrawal transactions, outgoing transfers, payments through savings accounts, and other fees are determined by the bank and should be less than similar transaction fees for regular savings accounts;

j. earn interest or profit-sharing starting from the account balance of IDR 1.00 (one rupiah); and

k. not allowed for joint accounts with "and/or" status. 
The bank can only give

(3) Savings with a Basic Saving Account characteristics to customers who do not have other savings.

(4) Banks are given the freedom to determine:

a. name of a savings product with the characteristics of a Basic Saving Account; and

b. form of proof of ownership of a savings account.

(5) If the number of nominal transactions in 1 (one) month exceeds the maximum limit as referred to in paragraph (2), letter $\mathrm{f}$ and letter $\mathrm{g}$ and/or the balance exceed the maximum limit of the account balance as referred to in paragraph (2) letter e. The customer still wants to make transactions and/or increase the account balance. The bank can change the status of the savings with the characteristics of the Basic Saving Account to become regular savings after:

1. The bank first requires a savings-holding customer with the characteristics of primary savings account to confirm approval; or

2. The Bank approves the customer's request who owns the Basic Saving Account characteristic to change the savings status from the Basic Saving Account characteristics to regular savings.

(6) If the Basic Saving Account balance is zero and/or there are no transactions for 6 (six) consecutive months, the status of the savings with the characteristics of the Basic Saving Account can be converted into a sleeping account (dormant account).

(7) Banks may only issue Automated Teller Machines (ATM) cards or debit cards to save customers with Basic Saving Account characteristics based on customer requests.

(8) If a Bank requires cooperation with a payment system operator in issuing an ATM card or debit card as referred to in paragraph (7), the collaboration must be made with a company that is legally incorporated in Indonesia and has a transaction processing location and data centre placement in Indonesia.

(9) Banks that have been approved as Laku Pandai operators are required to provide savings with the characteristics of Basic Saving Accounts at each bank office network.

In addition to collecting funds as Branchless Banking, there are also products for channelling funds as regulated in Article 6:

(1) Credit or financing for micro customers as referred to in Article 4 letter b shall be provided by the bank to customers holding savings with the characteristics of Basic Saving Accounts, in the following cases:

a. prospective debtors have been customers for at least 6 (six) months; or

b. the prospective debtor has become a customer for less than 6 (six) months. However, the bank has confidence about the prospective debtor's feasibility and/or financial capacity; and 
c. credit or financing is intended to finance productive business activities and/or other activities to support the realization of financial inclusion.

(2) Credit or financing for micro customers, as referred to in paragraph (1), has the following characteristics:

a. the maximum period of credit or financing is 1 (one) year; or

b. the credit or financing period may be longer than 1 (one) year as long as it is following the debtor's business cycle;

c. the maximum nominal credit or financing limit is set at a maximum of

Rp. 20,000,000.00 (twenty million rupiah)".

Applications for credit or financing for micro customers can be made through a network of bank offices or agents. The bank still carries out the feasibility analysis and approval of credit or financing applications. Disbursement of credit or financing for micro customers can be done through a savings account with the characteristics of the debtor's Basic Saving Account or an account belonging to the debtor's business needs provider. Banks are required to extend credit or productive financing to micro customers at least $70 \%$ (seventy per cent) of the total loan portfolio or financing for micro customers in the framework of Smart Practice.

\section{Banking to Support the Realization of Financial Inclusion}

According to Article 4 of Law Number 7 of 1992 (as amended by Law Number 10 of 1998) ("Banking Law"), the Indonesian banking industry aims to support national development in the context of justice, economic growth, and national stability towards increasing welfare. Lastly, I hope banks can help people lead better lives to lift the national economy. Banking stability is a shared responsibility. The achievement of banking objectives can not only be done by banks alone. However, it must be a form of cooperation and mutual support from all society and the government.

The financial services sector plays an essential role in financial inclusion, namely in channelling funds for the most productive uses and allocating risks to those who can manage them. One of the formal financial institutions mentioned in the National Strategy for Financial Inclusion is a Bank. ${ }^{30}$ According to the Indonesian National Financial Strategy, banking has advantages over other financial institutions; banks still dominate financial services as institutions that provide financial services and payments. Banking obligations as a financial services sector that supports financial inclusion are regulated in the Financial Services Authority Regulation Number 76/POJK.07/2016 concerning Increasing Financial Literacy and Inclusion in the Financial Services Sector for Consumers and/or Communities that financial service business actors are required to carry out activities to increase financial inclusion (Article 11 paragraph (1)).

\footnotetext{
30 "National Strategy for Inclusive Finance (Appendix Presidential Regulation No. 82 Year 2016 About the National Strategy for Inclusive Finance)" (n.d.). 
One of the initiatives that banks can take to encourage the Indonesian National Financial Strategy implementation is through branchless banking services. ${ }^{31}$ Branchless Banking can benefit banks in providing financial products that are easy to obtain, simple, easy to understand and meet the community's needs. Branchless banking anticipates that many areas of Indonesia do not yet have a network of financial service offices, the costs and time needed to reach people in the regions remote, simplifying the complexity of the banking service process while increasing knowledge of financial products and services. To operate Branchless Banking, it is enough to apply to become a Branchless Banking operator and obtain prior approval from the Financial Services Authority. ${ }^{32}$

Considering that banking has a role in achieving national development goals, banking is placed in a very strategic position. Government banking institutions must always carry out strict guidance and supervision. This is based on the premise that banking institutions in Indonesia can function efficiently, healthily, naturally, adequately protect funds entrusted by the public and channel these public funds to productive fields for achieving development targets. With the strategic function of banking institutions in the Indonesian economy, the condition of the banks must be healthy to create a healthy Indonesian economy. Banks are required to maintain a sound level following the capital adequacy ratio, asset quality, management quality, liquidity, profitability, and sensitivity to market risks and other aspects of the banking business.

In conducting business activities, a bank must be based on the principle of prudence. The precautionary principle brings consequences for banks. In collecting funds from the public and channelling them to the public, they are carried out prudently, carefully, thoroughly, wisely, or not carelessly by minimizing the possible risks that will occur. The objective of implementing the precautionary principle is to ensure that banks are always in a healthy condition, in other words, to ensure that they are always in a liquid and solvent condition. The principle of prudence is the principle that determines it in carrying out its functions and business activities. A bank is obliged to protect public funds entrusted to it by expecting that public trust in financial institutions remains high, so the public is willing and not hesitant to save funds in the bank. ${ }^{33}$

This mandate is also contained in the National Strategy for Financial Inclusion. Those exploration activities of various possibilities for innovative products, services, and distribution channels must pay attention to the principle of prudence. In implementing this precautionary principle in the case

\footnotetext{
${ }^{31}$ National Strategy for Inclusive Finance (Appendix Presidential Regulation No. 82 the Year 2016 About the National Strategy for Inclusive Finance).

32 Article 3 Regulation of the Financial Services Authority on Clever Practice

${ }^{33}$ Muhammad Djumhana, Hukum Perbankan Di Indonesia (Bandung: PT Citra Aditya Bakti, 1996).
} 
of credit extension, it is regulated in Article 8 of the Banking Law, which states: "In providing credit or financing based on Sharia Principles. Commercial Banks are required to have confidence based on in-depth analysis of the Debtor Customer's intention and ability as well as the ability to pay off their debts or return the said financing as agreed."

The interpretation of Article 8 of the Banking Law further explains that to reduce credit risk arising from credit extended by banks, banks must have complete confidence in the ability and ability of debtor customers to pay off their debts. To obtain this guarantee, banks must carefully evaluate debtor customers' characteristics, capabilities, capital, collateral, and business prospects before extending credit.

The precautionary principle is also regulated in Law Number 21 of 2001 concerning the Financial Services Authority Article 7, which includes:

1. Risk Management

The implementation of prudential principles of internal bank human resources principles of bank risk management. In the Financial Services Administration Regulation No. 18 / POJK.03 / 2016 concerning the Implementation of Commercial Bank Risk Management, it is defined as: "A series of methodologies and procedures used to identify, measure, monitor, and control risks arising from all of the Bank's business activities."

The risks that may arise include:

a. One of a kind. Reputation risk is caused by the decline in stakeholder trust and is considered detrimental to the bank.

b. Legal risk, namely the risk caused by weak linkages in litigation and/or law.

The bank's obligations in managing product risk and new activities are contained in Article 20 paragraph (1) of the Financial Services Authority Regulation Number 18/POJK.03/2016 concerning Application of Risk Management for Commercial Banks, namely:

"Banks are required to have written policies and procedures to manage the risks inherent in new products or activities of the bank, which at least include standard operating procedures and the authority to manage new products and activities, identify all risks inherent in the product, both those related to the bank. and customers, analysis of legal aspects for new products and activities, transparency of information to customers and so on."

2. Consumer Protection in the Financial Services Sector

Consumer protection is also a matter of legal risk management and reputation risk. Consumers can make lawsuits if consumers feel that aspects of consumer protection are not fulfilled or harmed. Financial Services Authority Regulation 1/POJK.07/2013 concerning Consumer Protection in the Financial Services Industry regulates consumer protection. This consumer protection implements several principles listed in Article 2 of the Consumer Protection Financial Services Authority Regulation, namely:

a. Transparency

b. Fair treatment 
c. Reliability

d. Confidentiality and security of consumer data/information

e. Handling complaints and resolving consumer disputes at a simple, fast, and affordable cost

3. Information Technology Risk Management

Administration Regulation 38/POJK.03/2016 concerning the Implementation of Risk Management in the Use of Information Technology by Commercial Banks, currently banks are deemed obliged to implement risk management in the use of technology. As a manifestation of an adequate information technology architecture to meet compliance demands. Application of the Indonesian Banking Architecture and the Basel II Accord.

The rules regarding the use of information technology are contained in Article 2 Application of Risk Management in the Use of Information Technology, which states: "Banks are required to implement risk management effectively in the use of information technology."

The operation of information technology by this bank can be done alone and/or with information technology service providers, as stipulated in Article 20 Application of Risk Management in the Use of Information Technology, that: "(1) Bank operates Information Technology; (2) The Information Technology Operators as referred to in paragraph (1) may be carried out by Banks themselves and/or information technology service providers. "

This is solely executed to support a strong, safe, efficient financial infrastructure and information and communication technology and has a broad reach. According to the National Strategy for Financial Inclusion, it will be very effective in providing more equitable financial products services. As per the requirements for the quality of information technology that Banks must meet, it is stipulated in Article 13 Application of Risk Management in the Use of Information Technology that: "Banks are required to provide a communication network that meets the principles of confidentiality, integrity and availability."

\section{Know Your Customer Principle}

This Aspect of Know Your Customer is also contained in the National Strategy for Financial Inclusion as a conducive policy and regulatory strategy implementation. This policy requires Principle's Know Your Customer in bank account accounting regulations for small customers to increase public access to savings. ${ }^{34}$

In general, it is necessary to understand the Financial Services Authority Regulation Number 23 of 2019 concerning Amendments to the Financial Services Authority Regulation 12/POJK.01/2017, which regulates the implementation of anti-money laundering and the prevention of terrorism financing.

${ }^{34}$ Djumhana. 
From the explanation above, it can be seen that the principles of prudence in banking include risk management, the principle of knowing customers and anti-money laundering, customer due diligence, and the analysis of credit application assessment by debtor customers.

Branchless Banking can also be one of the banking efforts in realizing the banking function as an intermediary institution, in line with the policy direction of the National Mid-Term Development Plan in the context of increasing economic added value in 2020-2024. The plan includes Strengthening the pillars of economic growth and competitiveness carried out by strategy; deepening the financial sector, both conventional and sharia, is carried out by, among others, increasing access to public finance (financial inclusion). ${ }^{35}$

\section{The Bank's Prudential Principle Towards Cooperation Agreements with Agents in Providing Smart Practice Services to Support the Realization of Financial Inclusion}

Procedures for cooperating with other parties (bank agents in this case) to provide banking services and/or other financial services and support them through information technology facilities. Considering that many people do not know, use and obtain banking and other financial services, it is necessary to "practice wisely" because they live far from bank offices and/or burdensome fees or requirements. The Financial Services Authority, banking, and other financial services industries are committed to supporting financial inclusion.

Banks have committed to developing financial inclusion by expanding financial services to the public through banking to develop financial inclusion in Indonesia. Financial inclusion is a comprehensive activity that aims to remove all forms of barriers to public access in utilizing financial services supported by various supporting infrastructures.

Access to financial services is necessary for people who do not understand, use, and/or obtain banking services and other financial services. The bank is committed to supporting financial inclusion, which the government has also announced to expand access to financial services. One manifestation of the commitment of the financial services industry that has been embodied as one of the National Strategy for Financial Inclusion programs is the provision of branchless banking services. Through branchless banking, financial products are available that Easy to access, simple, easy to understand, and as needed to support financially inclusive societies.

Officeless financial services for financial inclusion or branchless banking provide banking services and/or other financial services are carried out not

\footnotetext{
${ }^{35}$ Presidential Regulation No.18 of 2020 on the National Medium Term Development Plan 2020-2024
} 
through office networks but in cooperation with other parties. It also requires information to support their technical facilities, providing banking products to people who have not provided services through the bank office network.

With the strategic function of banking institutions in the Indonesian economy, the condition of the banks must be healthy to create a healthy Indonesian economy. Banks are required to maintain a stable level following the provisions of the capital adequacy ratio, asset quality, management quality, liquidity, profitability, and sensitivity to market risk and other aspects related to bank business.

In conducting business activities, a bank must be based on the principle of prudence. The precautionary principle brings consequences for banks. In collecting funds from the public and channelling them to the public, they are carried out prudently, carefully, thoroughly, and wisely or not carelessly by minimizing the possible risks that will occur. The objective of implementing the precautionary principle is to ensure that banks are always in a healthy condition, in other words, to ensure that they are always in a liquid and solvent condition. The principle of prudence is the principle that determines it in carrying out its functions and business activities; a bank is obliged to act prudently to protect public funds entrusted to the bank.

This mandate is also contained in the National Strategy for Financial Inclusion. Those exploration activities of various possibilities for innovative products, services, and distribution channels must pay attention to the principle of prudence. The precautionary principle is also regulated in Law No. 21 of 2011 concerning Financial Services Authority Article 7, which includes applying risk management. Risks that may occur include reputation risk (from a negative bank point of view, namely risk caused by decreased stakeholder trust) and legal risk (namely risk due to lawsuits and/or legal weaknesses).

The bank's obligations to manage product and activity risk areas are contained in the Financial Services Authority Regulation Number 18/POJK.03/2016 concerning the Implementation of Risk Management for Commercial Banks, namely, banks must have policies and procedures in writing to manage the risks inherent in new products or activities. Banks, which include standard operational procedures, the authority to manage new products and activities, identify all risks inherent in the product, those related to banks and customers, analysis of legal aspects for new products and activities, transparency of information to customers, and so on.

Consumer protection is also a matter of legal risk management and reparation risk; consumers can make lawsuits if consumers feel that aspects of consumer protection are not fulfilled or harmed. Consumer protection is regulated in the Financial Services Authority Regulation Number 1/POJK.07/2013 concerning Consumer Protection in the Financial Services Sector. This consumer protection applies some principles listed in Article 2 of the Regulation of the Financial Services Authority for consumer protection: 
Transparency, Fair Treatment, Reliability, Confidentiality, and security of consumer data/information and handling complaints resolving consumer disputes in a simple, fast, and affordable cost.

Based on the amendment to the Financial Services Authority Regulation Number 38/POJK.03/2016, banks are required to implement effective risk management in the use of information technology, stipulated in the Financial Services Authority Regulation Number 13/POJK.03/2020. Regarding the management and application of commercial bank risk in the use of information technology in 2016. It is currently believed that banks have adopted technology-based risk management as an appropriate form of information technology architecture to meet the needs of information technology applications of the Indonesian Banking System and "Basel II".

This bank's operation of information technology can be done alone and/or with information technology service providers. This is solely executed to support a strong, safe, efficient financial infrastructure of Information and Communication Technology and has a wide reach. According to the National Strategy for Financial Inclusion, it will be very effective in providing more equitable financial products services. Banks must meet information technology quality requirements in providing a communication network that meets the principles of confidentiality, integrity, and availability.

Banks are also required to apply the Principle of Knowing Your Customer and Anti Money Laundering Principles. This Aspect of Know Your Customer is also contained in the National Strategy for Financial Inclusion as a conducive policy and regulatory strategy implementation, which requires Know Your Customer in bank account bookkeeping regulations for small customers to increase public access to savings. This Principle of Know Your Customer implementation is also related to the Prevention of Terrorism Financing and Banking Crime (Customer Due Diligence / CDD).

Thus, prudential banking principles include risk management, knowcustomer and anti-money laundering principles, customer due diligence, and in-depth analysis of credit application assessments by debtor customers.

\section{The Bank's Responsibility If the Agent Harms the Customer in Implementing Smart Practice Services}

Every Financial Service Institution that operates Branchless Banking is Must obtain approval from the Financial Services Authority. Banks that can apply to become Branchless Banking organizers after being approved to become Branchless Banking providers must implement risk management and prudence principles in implementing smart practices. As a manifestation of one of the pillars of Indonesian inclusive finance, namely consumer protection, in every Branchless Banking service that banks implement. They are required to always apply the principle of prudence through their agents to protect public funds entrusted to the bank protecting the bank's reputation. 
As one manifestation of applying the principle of prudence in Smart Practice, it is the obligation to record every transaction. Transactions carried out by customers of Branchless Banking administering bank must be recorded in the customer's account in the core banking system owned by the bank at the same time (real-time). The bookkeeping of these transactions is accompanied by submitting proof of transactions to customers of the bank concerned.

Transactions include, among other things, cash deposits and withdrawals, book-entry, payments, fund transfers, checking balances, and/or depositing of billing results receiving instalments or principal redemptions. Proof of transaction includes, among other things, a savings book, statement sheet, SMS notification, or proof of transaction printed out. Fund transfers, which are transactions made by consumers to agents, are also services covered by real-time regulations.

Funds transfer transactions conducted by customers must be recorded in the customer's account in the core banking system, namely through the agent's electronic device and using the related customer's account. This is to avoid the deposition of money on the agent, meaning that every transaction service is carried out right away without any form of delay, for example, on another transaction or the agent receiving money with a significant delay after the first transaction is made.

If a customer conducts a non-cash transaction, the transaction bookkeeping is accompanied by submitting proof of the transaction to the bank's customer. One of the requirements for the availability of information technology infrastructure is that this information technology must process and record transactions in real-time to the customer's account. That does not mean cash transactions. This rule is ignored because it also applies to transactions such as deposits and withdrawals. In the case of non-cash transactions, it requires the agent to transfer funds used as operational funds for the agent. The agent's operational funds are transferred to the account address designated by the customer. Funds replace the agent's funds from the customer in cash, so this real-time regulation should still be applied with adjustments to the non-cash transaction mechanism. However, the agent's lack of knowledge about this regulation causes the agent to continue to experience negligence, resulting in various cases. The minimal knowledge of agents by regulators from the start was anticipated by the existence of a Standard Operational Procedure set out in a Circular Letter of the Branchless Banking Financial Services Authority.

The agent has responsibilities stem from the laws and regulations and the agreement between each agent and each administering bank. The Panda Business Agent is fundamentally responsible for carrying out all obligations based on the prevailing laws and regulations for the conduct of banking activities in general. Errors due to the negligence of the agent which legal consequences are the responsibility of the agent. The bank still has the same responsibility in providing adequate education to the agent, which in these cases shows that there is still a need for improvement in education to the agent. 
There are several violations in the practice of agents, among others, that customers pay additional fees other than those listed in the list of types of services and associated fees. ${ }^{36}$ And violations regarding the confidentiality of Personal Identification Numbers and/or passwords to agents result from frequent transactions failing due to weak signals in the area and poor quality electricity, which ultimately causes this agent to accept the deposit of money PINs from customers. A PIN is one of the tools used in implementing the principle of authenticity. Banks are required to apply the principles of controlling customer data security and e-banking transactions in the electronic system to implement Branchless Banking as referred to in the provisions regarding the application of risk management in the use of bank information technology. In implementing the principle of authenticity, the bank administering branchless banking has at least two authenticity factors. In implementing the non-repudiation principle, the Branchless Banking organizing bank implements messaging security and end-to-end encryption.

The bank is responsible for the agent's actions that harm its customers, considering that in implementing smart behaviour, the agent acts for and on behalf of the bank. Even though the bank did not make a mistake, because the agent is an extension of the bank, then based on the Civil Code, a person will also be responsible for people's actions under his responsibility or objects under his control. Article 1367 of the Civil Code states: "A person is not only responsible, for losses caused by his actions, but also for losses caused by the actions of those who are dependent on him or due to goods under his control." The basis of employer responsibility for mistakes committed by employees.

Accountability must have a basis, namely things that give rise to a legal right for one person to sue another as well as things that give birth to someone else's legal obligation to give his accountability. ${ }^{37}$ Based on the type of legal relationship that exists, liability can be divided into: ${ }^{38}$

1. Liability based on error, namely responsibility arising from illegal acts and careless actions.

2. Accountability based on risk, namely the responsibility that must be borne because of the risks a business actor must take on his business activities.

The principle of responsibility based on mistakes (liability based on fault) is a principle that states that a person is only legally held accountable if his/her wrongdoing are fulfilled. This refers to Article 1365 of the Civil Code: "Every act that is against the law and brings harm to others obliges the person who caused the loss due to his mistake to compensate for the loss". The actions referred to in Article 1365 of the Civil Code require the fulfilment of four

\footnotetext{
${ }^{36}$ I.E., Thalassinos and K Liapis, "Segmental Financial Reporting and the Internationalization of the Banking Sector. Chapter Book Risk Management: Strategies for Economic Development and Challenges in the Financial System," 2014.

${ }^{37}$ Titik Triwulan and Shinta Febrian, Pelindungan Hukum Bagi Pasien (Jakarta: Prestasi Pustaka, 2010).

${ }^{38}$ Janus Sidabalok, Hukum Perlindungan Konsumen (Bandung: Citra Aditya Bakti, 2014). 322
} 
elements in the fulfilment of "acts against the law". There must be an error in the form of deliberate action or negligence, the loss incurred, and there is a causal relationship between the act and the loss. Article 1365 of the Civil Code is the legal basis for any person who commits an act that violates the law which may cause harm to other parties; he is obliged to compensate for the loss.

The bank is responsible for the agent's actions, which are included in the scope of the agent's services as stated in the cooperation agreement. The bank is required to monitor and supervise the agent's activities directly, either periodically or incidentally. The bank's obligation to provide guidance and/or impose sanctions for violations committed by the agent. Optimally education and training for agents and providing education and literacy to the community around the agent's location regarding the products offered. Banks must ensure the responsibility for the continuity of Branchless Banking implementation in certain conditions that result in the inability of the agent to operate.

The bank monitoring includes checking the agent's location to ensure the agent's suitability of service provision with the agent's classification and service coverage in the cooperation agreement. The bank determines the frequency of direct monitoring and supervision by considering, among others, the factor of security, confidence in the agent's credibility and integrity, the results of monitoring analysis of Agent transactions, and developments in the agent's business activities the number of deposits.

Collaboration with agents can increase the risk faced by the bank, so much cooperation must be carried out by applying the principles of prudence and proper risk management. Additionally, the clarity of the bank's responsibilities towards agents and customer protection aspects are essential to pay attention to. Strengthening the application of prudential principles and risk management in cooperation with agents and protecting customer interests are expected to maintain the integrity of the banking system in particular and the financial system as a whole.

\section{Conclusion}

1. The principle of bank prudence regarding cooperation agreements with agents in providing Branchless Banking services to support the realization of financial inclusion. It also requires banks to implement risk management effectively in the use of information technology, Know Your Customer and Anti Money Laundering Principles, customer due diligence, and in-depth analysis of the assessment of credit applications by debtor customers.

2. The bank's liability if the agent acts and acts detrimental to his customers, considering that in implementing clever behaviour, the agent acts for And the bank has to compensate for the loss on behalf of the bank. Even if the bank does not make a mistake because the agent is an extension, the person must also be responsible following Article 1367 of Civil Law. Actions of people under his/her dependents or objects under their supervision. 


\section{Recommendations}

In anticipating reputation risk, namely the risk of decreasing public confidence due to opposing views on banks, banks are more selective in working with agents. Considering that the agent is an extension of the bank's arm, it represents and acts on behalf of the bank in providing branchless banking services.

In line with the increasing number of smart behaviour service users in various regions in Indonesia, people hope that people's economic activities can run smoothly to encourage economic growth and equitable development in Indonesia, especially between urban and rural areas. However, transactions often fail due to weak signals and poor power quality in remote areas. Therefore it is necessary to upgrade the internet network with solid calls to remote areas. Therefore, the purpose of branchless banking services is to provide convenience and ease of access. Use banking services Learn about suitable financial services and products. Thus, services can achieve the community's needs.

\section{References}

Ajeng Noorseta Quadtias Kumitirasih. "Tanggungjawab Agen Layanan Keuangan Tanpa Kantor Dalam Rangka Keuangan Inklusif Terhadap Rahasia Bank." Kumpulan Jurnal Mahasiswa Fakultas Hukum 0, No. 0 (2015).

Http://Hukum.Studentjournal.Ub.Ac.Id/Index.Php/Hukum/Article/Vie w/1160.

C, Edquist, And Hommen L. "Systems Of Innovation: Theory And Policy For The Demand Side." Technology In Society2 1, 1999, 63-79.

Cahyaningrum, Dian. "Pelindungan Nasabah Dalam Penyelenggaraan Laku Pandai: Studi Pelindungan Nasabah Laku Pandai BCA Di Jawa Tengah Dan BRI Di Papua (Consumer Protections In 'Laku Pandai' Implementation: Study Of BCA 'Laku Pandai' Consumer Protection In Middle Java And BRI 'Laku Pandai' Consumer Protection In Papua)."

Negara Hukum: Membangun Hukum Untuk Keadilan Dan Kesejahteraan 7, No. 2 (December 27, 2017): 213-34. Https://Doi.Org/10.22212/Jnh.V7i2.932.

Chim, Catherine Tay Swee Kian Tang See. Contract Law. Singapore: Times Books International, 1993.

Danrivanto Budijanto. Hukum Telekomunikasi, Penyiaran Dan Teknologi Informasi: Regulasi Dan Konvergensi. Bandung: Refika Aditama, 2010. Djumhana, Muhammad. Hukum Perbankan Di Indonesia. Bandung: Pt Citra Aditya Bakti, 1996.

Fajar., Mukti, And Yulianto Achmad. Dualisme Penelitian Hukum Normatif Dan Empiris. Yogyakarta: Pustaka Pelajar, 2010.

Febriarti, Primitiva. "Agen Sang Ujung Tombak." In Gerai Info Bank 
Indonesia, 12, June 2013.

Hakim, Lukmanul, Etty Mulyati, Djuhaendah Hasan, And Tarsisius Murwadji. "Legal Aspects Of Micro Business Development Institutions In State Purpose Of Welfare." Fiat Justisia:Jurnal Ilmu Hukum 14, No. 3 (May 15, 2020): 260. Https://Doi.Org/10.25041/Fiatjustisia.V14no3.1804.

Hermansyah. Hukum Perbankan Nasional Indonesia. Jakarta: Prenada Media Group, 2007.

Inda Rahadiyan, And M. Alif Akbar Pranagara. "Bentuk Hubungan Hukum

Para Pihak Dan Tanggung Jawab Agen Dalam Penyelenggaraan Branchless Banking Di Indonesia.” Jurnal Hukum Ius Quia Iustum 24, No. 2 (2017): 314.

Janus Sidabalok. Hukum Perlindungan Konsumen. Bandung: Citra Aditya Bakti, 2014.

Kasmir. Dasar-Dasar Perbankan. Jakarta: Raja Grafindo Persada, 2002.

"Laku Pandai - Layanan Keuangan Untuk Semua." Accessed February 10, 2021. Https://Sikapiuangmu.Ojk.Go.Id/Frontend/Cms/Article/191.

Maulana, Rivki. “Ojk Andalkan Agen Laku Pandai.” Bisnis.Com, 2015. Https://Finansial.Bisnis.Com/Read/20150413/90/422379/Ojk-

Andalkan-Agen-Laku-Pandai.

Mubarok, Rizki, Budi Santoso, And Rinitami Njatrijani. "Pertanggungjawaban Agen Branchless Banking Terhadap Nasabah Branchless Banking (Hubungan Hukum Antara Agen-Prinsipal Dan Konsumen)." Diponegoro Law Journal 6, No. 2 (April 20, 2017): 1-12. Https://Ejournal3.Undip.Ac.Id/Index.Php/Dlr/Article/View/19636.

Muniarty, Puji, Nurhayati Nurhayati, And Ita Purnama. "Analisis Laku Pandai (Branchless Banking) Pada Agen Perbankan (Studi Di Kota Bima)." Jurnal Mitra Manajemen 3, No. 7 (July 31, 2019): 802-14. Https://Doi.Org/10.52160/Ejmm.V3i7.259.

National Strategy For Inclusive Finance (Appendix Presidential Regulation No. 82 Year 2016 About The National Strategy For Inclusive Finance) (ND).

Presidential Regulation No.18 of 2020 on the National Medium Term Development Plan 2020-2024

Putri, Syah Amelia Manggala, And Eka Jati Rahayu Firmansyah. "Optimalisasi Laku Pandai Berbasis Masjid Guna Literasi Dan Inklusi Keuangan Syariah Berkelanjutan.” Jurnal Ekonomi Dan Bisnis Islam (Journal Of Islamic Economics And Business) 3, No. 2 (March 7, 2017): 106. Https://Doi.Org/10.20473/Jebis.V3i2.6464.

Ramdhany, Priadhi Harry. "Hubungan Hukum Antara Bank Dengan Agen Laku Pandai (Branchless Banking) Dalam Pelaksanaan Perantara Keuangan (Financial Intermediary) Dihubungkan Dengan Prinsip Kepercayaan (Fiduciary Principle)." Aktualita (Jurnal Hukum) 2, No. 2 (December 23, 2019): 455-72. 
Https://Doi.Org/10.29313/Aktualita.V2i2.4841.

Regulation of the Financial Services Authority on Clever Practice

Riduan Syahrani. Seluk Beluk Dan Asas-Asas Hukum Perdata. Bandung: Pt.Alumni, 2004.

Rushandie, Roby. "Branchless Banking Lebih Dari Sekedar Jargon Marketing." $\quad$ Accessed $10 \quad$ February 2021.

Http://Www.Kompasiana.Com/Rushandie/Branchless-Banking-Lebih-

Dari-Sekedar-Jargonmarketing_54f94820a3331150278b4816.

Sari, Putu Ayu Sruti Permata, And Budi Frensidy. "Analisis Penerapan

Program Laku Pandai Pada Pt Xyz.” Jurnal Ilmu Manajemen Dan Bisnis 10, No. 2 (2019): 131-42. Https://Doi.Org/10.17509/Jimb.V10i2.16997.

Sastiono, Prani, And Chaikal Nuryakin. "Inklusi Keuangan Melalui Program Layanan Keuangan Digital Dan Laku Pandai." Jurnal Ekonomi Dan

Pembangunan Indonesia 19, No. 2 (December 14, 2019): 242-62. Https://Doi.Org/10.21002/Jepi.V19i2.1228.

Subekti. Hukum Perjanjian. Jakarta: Intermasa, 2005.

Surbakti, Tesa Oktiana. "Ojk Terus Tingkatkan Akses Keuangan Masyarakat." Accessed $\quad 2021$. Https://Mediaindonesia.Com/Ekonomi/276954/Ojk-Terus-Tingkatkan-

Akses-Keuangan-Masyarakat.

Sutan Remy Sjahdeini. "Rahasia Bank:Berbagai Masalah Disekitarnya." Jakarta, 2008.

Https://Korup5170.Files.Wordpress.Com/2008/06/Rahasiabank.Pdf.

Thalassinos, I. E. D.T.Stamatopoulos, And E. P. Thalassinos. "The European Sovereign Debt Crisis And The Role Of Credit Swaps. Chapter Book W.

T. Ziemba And A.G. Malliaris,' The Wspc Handbook Of Futures Markets' (Eds), In Memory Of Late Milton Miller (Nobel 1990) World Scientific Handbook In Financial Economic." 5, 2015. Https://Doi.Org/10.1142/9789814566926_0020.

Thalassinos, I.E., And K Liapis. "Segmental Financial Reporting And The

Internationalization Of The Banking Sector. Chapter Book Risk Management: Strategies For Economic Development And Challenges In The Financial System," 2014.

Triwulan, Titik, And Shinta Febrian. Pelindungan Hukum Bagi Pasien. Jakarta: Prestasi Pustaka, 2010. 